\title{
Engineered Bone Development from a Pre-Osteoblast Cell Line on Three-Dimensional Scaffolds
}

\author{
LONNIE D. SHEA, Ph.D.,${ }^{1,2}$ DIAN WANG, ${ }^{3}$ RENNY T. FRANCESCHI, ${ }^{3}$ \\ and DAVID J. MOONEY, Ph.D., ${ }^{1,2,4}$
}

\begin{abstract}
Bone regeneration is based on the hypothesis that healthy progenitor cells, either recruited or delivered to an injured site, can ultimately regenerate lost or damaged tissue. Three-dimensional porous polymer scaffolds may enhance bone regeneration by creating and maintaining a space that facilitates progenitor cell migration, proliferation, and differentiation. As an initial step to test this possibility, osteogenic cells were cultured on scaffolds fabricated from biodegradable polymers, and bone development on these scaffolds was evaluated. Porous polymer scaffolds were fabricated from biodegradable polymers of lactide and glycolide. MC3T3-E1 cells were statically seeded onto the polymer scaffolds and cultured in vitro in the presence of ascorbic acid and $\beta$-glycerol phosphate. The cells proliferated during the first 4 weeks in culture and formed a space-filling tissue. Collagen messenger RNA levels remained high in these cells throughout the time in culture, which is consistent with an observed increase in collagen deposition on the polymer scaffold. Mineralization of the deposited collagen was initially observed at 4 weeks and subsequently increased. The onset of mineralization corresponded to increased mRNA levels for two osteoblast-specific genes: osteocalcin and bone sialoprotein. Culture of cell/polymer constructs for 12 weeks led to formation of a three-dimensional tissue with architecture similar to that of native bone. These studies demonstrate that osteoblasts within a three-dimensional engineered tissue follow the classic differentiation pathway described for two-dimensional culture. Polymer scaffolds such as these may ultimately be used clinically to enhance bone regeneration by delivering or recruiting progenitor cells to the wound site.
\end{abstract}

\section{INTRODUCTION}

B ONE DEFECTS, which result from tumors, diseases and infections, trauma, biochemical disorders, and abnormal skeletal development, pose a significant health problem. For example, removal of bone tumors can create a critical size defect, which needs to be regenerated to provide skeletal continuity and mechanical support. ${ }^{1}$ Periodontal disease, which severely affects approximately $10 \%$ of the adult population, ${ }^{2}$ is characterized by a loss of attachment between the tooth and underlying bone and bone resorption, and can

Departments of ${ }^{1}$ Biologic and Material Science, ${ }^{2}$ Biomedical Engineering, ${ }^{3}$ Periodontics/Prevention/Geriatrics, and ${ }^{4}$ Chemical Engineering, University of Michigan, Ann Arbor, Michigan. 
ultimately lead to tooth loss. Current therapies (e.g., autografts, allografts, and metal prostheses) for bone regeneration or replacement are limited ${ }^{1}$ and have inspired a search for improved methods for repairing skeletal defects.

Guided bone regeneration (GBR), or alternatively guided tissue regeneration (GTR) represent a new direction toward bone regeneration. ${ }^{3,4}$ This strategy is based on the premise that progenitor cells capable of tissue regeneration reside in the surrounding tissue. The goal of this strategy is to provide an appropriate environment to induce cell migration from the surrounding tissue into the wound/diseased site. Subsequently, the progenitor cells proliferate, differentiate, and ultimately regenerate the tissue. To provide this environment, a barrier is often used that is intended to allow selective repopulation of the wound site by progenitor cells. This strategy has proven successful clinically; however, current approaches frequently result in inconsistent or incomplete regeneration resulting from the inability to create and maintain the appropriate environment in vivo for tissue regeneration. ${ }^{5}$

Tissue engineering, in contrast, attempts to create tissue replacements by culturing cells on synthetic three-dimensional polymer scaffolds. ${ }^{6}$ These scaffolds must satisfy several requirements to provide a suitable environment for tissue development. ${ }^{7}$ They must create and maintain a space in vivo and ultimately control the size and shape of the regenerated tissue. Highly porous scaffolds, with pore diameters greater than a cell diameter, provide space within the scaffold for tissue development while allowing cells from the surrounding tissue to migrate into the scaffold. ${ }^{8}$ The surface of the polymer must provide sites for cell attachment because many cells are anchorage dependent and require a support for survival. As the cells begin to regenerate the tissue, it is desirable to have the scaffold biodegrade to leave behind a completely natural tissue. Recently, a novel gas foaming/particulate leach approach has been developed that allows fabrication of porous $(>95 \%)$ scaffolds with the desired properties from synthetic copolymers of lactide and glycolide (PLG). ${ }^{9}$ PLG has been used extensively in the biomaterials field and is generally considered to be biocompatible. Additionally, the degradation rate of the scaffold can be controlled through the appropriate choice of the lactide-to-glycolide ratio in the polymer. ${ }^{10}$

Culture of MC3T3-E1 cells, an osteogenic cell line, on these porous PLG scaffolds was performed to determine if the scaffolds provide an environment that supports the formation of mineralized tissues. In addition, the scaffolds provide a model system to examine the development of a three-dimensional mineralized tissue from bone progenitor cells in vitro. This study specifically analyzed whether bone formation on the polymer scaffolds follows the accepted model of osteoblast differentiation outlined for two-dimensional systems. ${ }^{11,12}$ Ultimately, these scaffolds may find use clinically as cell transplantation vehicles or for guiding bone regeneration.

\section{MATERIALS AND METHODS}

\section{Scaffold fabrication}

Porous matrices of PLG were fabricated using a previously described gas foaming/particulate leaching process. ${ }^{9}$ Briefly, an 85:15 copolymer of D,L-lactide and glycolide (PLG) (Boehringer, Ingelheim Henley, Montvale, NJ) was milled, and the resulting particles were sieved to a particle size ranging between 106 and $250 \mu \mathrm{m}$. PLG particles were subsequently mixed with $\mathrm{NaCl}$ (Fisher, Pittsburgh, PA) and compression molded. The resulting disc was placed in a pressure vessel and exposed to $\mathrm{CO}_{2}$ at 800 psi for $48 \mathrm{~h}$. Release of the pressure causes the polymer particles to expand and fuse leading to an interconnected polymer network. Immersion of the disc in water for $24 \mathrm{~h}$ leaches the $\mathrm{NaCl}$ and creates a porous scaffold. This process creates matrices that are $95 \%$ porous with pore diameters ranging from 250 to $400 \mu \mathrm{m} .{ }^{9}$

\section{Cell culture}

MC3T3-E1 cells were a generous gift from Dr. M. Kumegawa (Josai Dental University, Sakado, Japan). Stock cultures were grown in AA-free $\alpha$-modified Eagle's medium (MEM- $\alpha$ ) and $10 \%$ fetal calf serum (FCS; HyClone Labs Logan, UT) containing 100 units/mL of penicillin and streptomycin (Gibco BRL, Gaithersburg, MD) and passaged every 3-4 days. Cells between passages 6 and 8 were statically seeded onto the porous polymer matrices as previously described. ${ }^{13}$ Cell-polymer constructs were cultured in a 
spinner flask (Bellco Glass, Inc., Vineland, NJ) at $25 \mathrm{rpm}$ in $\alpha$-MEM containing $10 \%$ FBS and supplemented with $50 \mu \mathrm{g} / \mathrm{mL}$ ascorbic acid (Aldrich, Milwaukiee, WI) and $10 \mathrm{mM} \beta$-glycerol phosphate (Aldrich).

\section{Histology}

Cells cultured on matrices were fixed in 10\% formalin (Sigma, St. Louis, MO), dehydrated, and embedded in paraffin using standard procedures. Sections ( $5 \mu \mathrm{m}$ thick) were then cut and mounted. Hema-

A

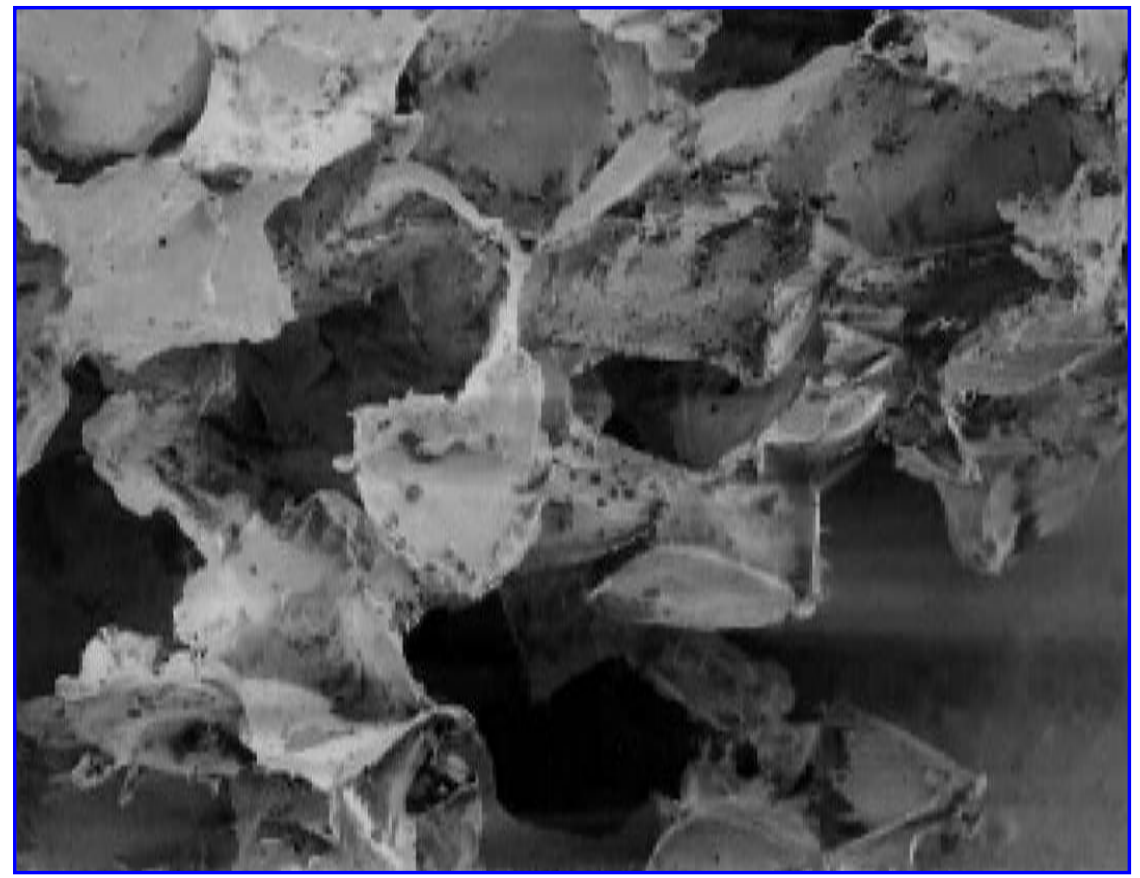

B

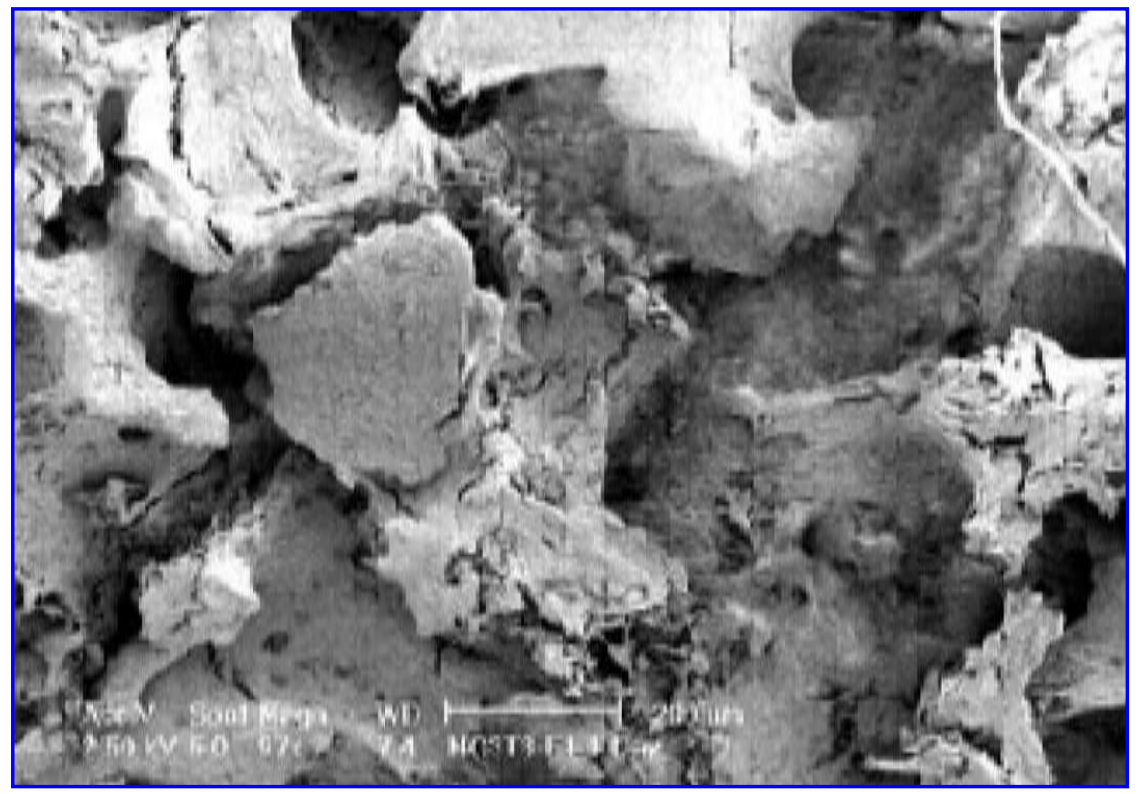

FIG. 1. Porous PLG scaffold for engineering tissues. Scanning electron photomicrographs of PLG scaffold (A) (no cells) and PLG scaffold (B) seeded with MC3T3-E1 cells and cultured for 1 day. (Original magnification: $(\mathbf{A}) \times 38$ and (B) $\times$ 97.) 
toxylin \& Eosin, Masson's trichrome, and von Kossa staining were performed on sections according to standard protocols. ${ }^{14}$

\section{Assays}

Cell number on the scaffold was determined using a DNA assay. ${ }^{13}$ Matrices were placed in a proteinase $\mathrm{K}$ (Sigma) solution for $10 \mathrm{~h}$ at $55^{\circ} \mathrm{C}$. The total amount of DNA was subsequently determined using the Hoechst 33258 dye and a fluorometer (Hoefer DyNA Quant 200, Pharmacia Biotech, Uppsala, Sweden). The concentration of DNA in solution was converted to a cell number using a conversion factor of $8 \mathrm{pg}$ of DNA per MC3T3-E1 cell. This conversion factor was determined by measuring the amount of DNA from a known cell number. Statistical analysis for all assays was performed using the software package InStat (Graph Pad Software, San Diego, CA).

For measurement of phosphate in the scaffold, matrices were placed in a 15\% trichloroacetic acid (Fisher) solution for $24 \mathrm{~h}$. Supernatants were then assayed for phosphate using the method of Heinonen and Lahti. ${ }^{15}$

To determine the rate of osteocalcin production by cells cultured on the polymer scaffold, matrices were placed in fresh media and incubated for $24 \mathrm{~h}$ at $37^{\circ} \mathrm{C}$. Media were collected and analyzed for the quantity of osteocalcin with a radioimmunoassay. Regents for the assay were purchased from Biomedical Technologies Inc. (Stoughton, MA). The measured quantities were normalized with the average number of cells on the scaffold.

\section{RNA isolation and analysis}

Total RNA was isolated from tissues developed on the PLG scaffolds by homogenization of the scaffold with a polytron (Brinkman Instruments Inc., Westbury, NY). RNA was extracted as described by Chom-

A

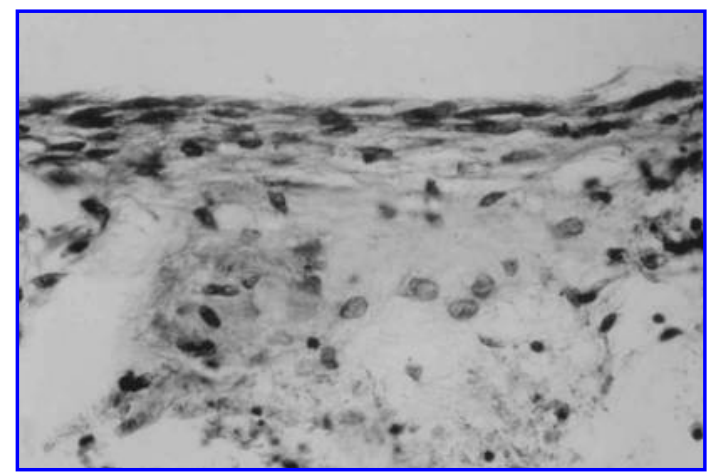

$\mathbf{C}$

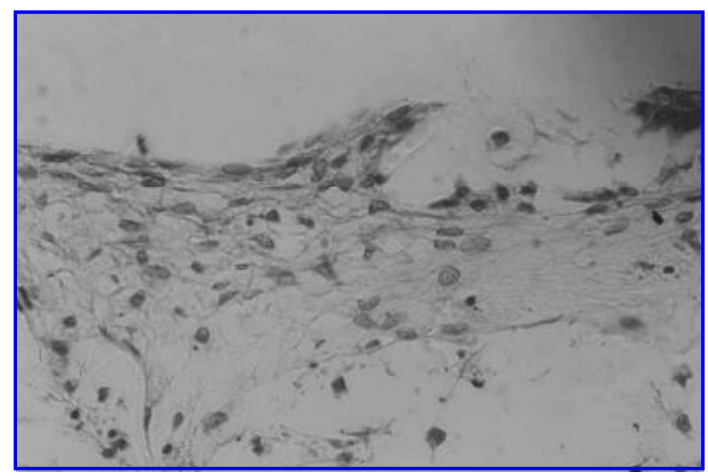

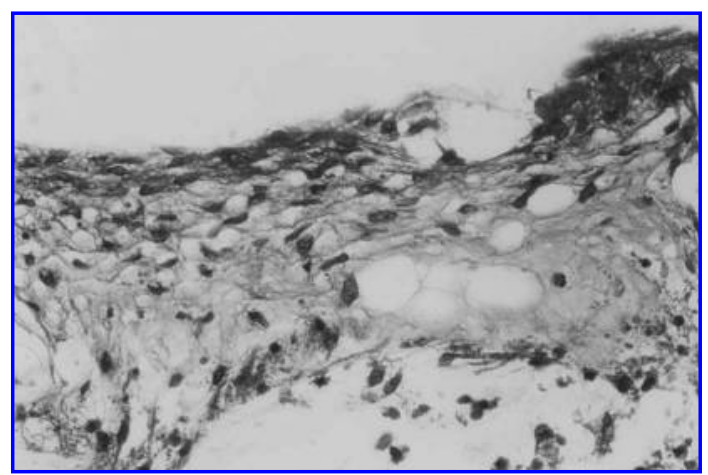

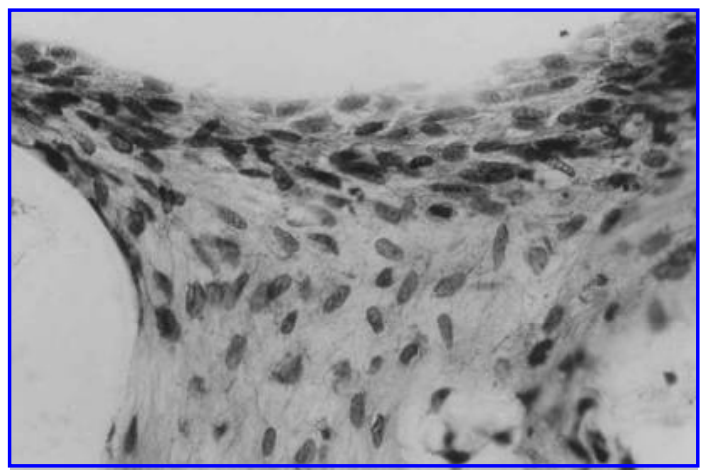

FIG. 2. Tissue development from culture of MC3T3-E1 cells on PLG scaffolds. Photomicrographs of histological sections for MC3T3-E1 cells cultured on PLG matrices for 2 weeks (A-C), 4 weeks (D-F), and 12 weeks (G-I). A, D, and $\mathbf{G}$ show sections stained with Hematoxylin \& Eosin. B, E, and $\mathbf{H}$ show sections stained with Masson's trichrome. C, F, and I show sections stained with von Kossa procedure. (Original magnification: $\times 400$.) 
czynski and Sacchi. ${ }^{16}$ In brief, the method involves initial purification of total nucleic acid by extraction with phenol, chloroform, and isoamyl alcohol followed by selective precipitation of RNA with sodium acetate at $\mathrm{pH}$ 6.0. Aliquots of total RNA were fractionated on $0.8 \%$ agarose-formaldehyde gels and blotted onto nitrocellulose paper with 20 -fold standard saline citrate buffer (SSC) as described by Thomas. ${ }^{17} \mathrm{cDNA}$ probes used for hybridization were obtained from the following sources: mouse osteocalcin from Dr. John Wozney (Genetics Institute, Boston, MA), ${ }^{18}$ mouse bone sialoprotein ${ }^{19}$ from Dr. Marian Young (National Institute of Dental and Craniofacial Research, Bethesda, MD), and human collagen $\alpha 1$ (I). ${ }^{20}$ All cDNA inserts were excised from plasmid DNA with the appropriate restriction enzymes and purified by agarose gel electrophoresis before labeling with $\left[\alpha-{ }^{32} \mathrm{P}\right] \mathrm{dCTP}$ (deoxycytosine triphosphate) using a random primer kit (Boehringer-Mannheim, Indianapolis, IN). All prehybridizations and hybridizations were performed in 50\% formamide; five-fold SSC, five-fold Denhardt's solution; $50 \mathrm{mM}$ phosphate buffer, $\mathrm{pH} 6.5$; $1 \%$ sodium dodecyl sulfate (SDS); and $250 \mathrm{mg} / \mathrm{mL}$ of herring sperm DNA at $42^{\circ} \mathrm{C}$ using an Autoblot hybridization oven (Bellco Glass). Hybridization buffer contained $1 \times 10^{6} \mathrm{dpm}$ denatured probe per milliliter. Following hy-

$\mathbf{E}$

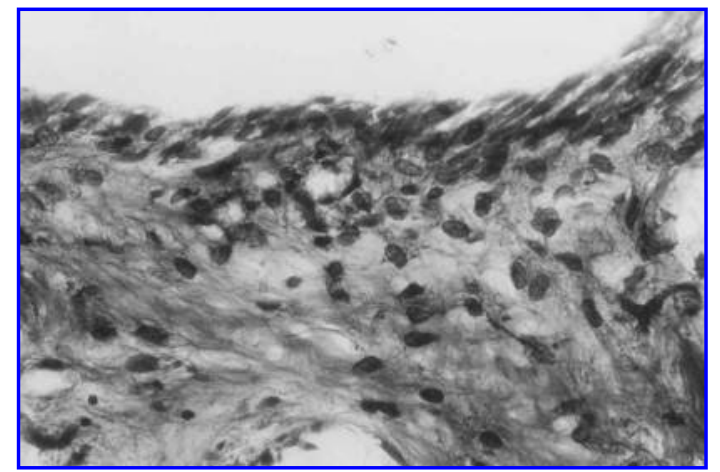

G

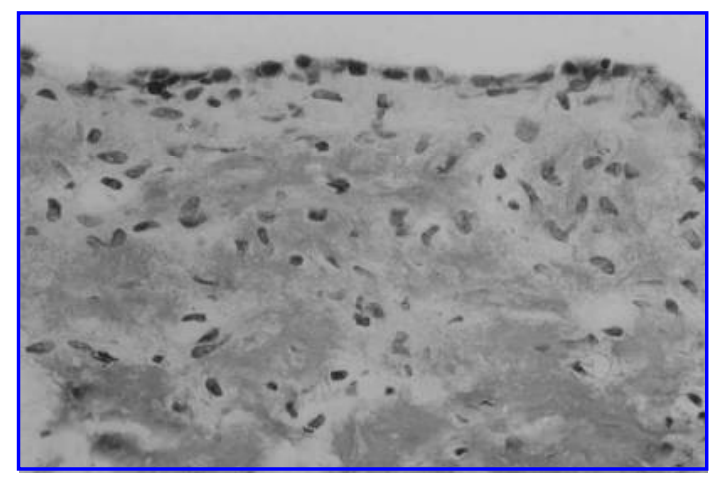

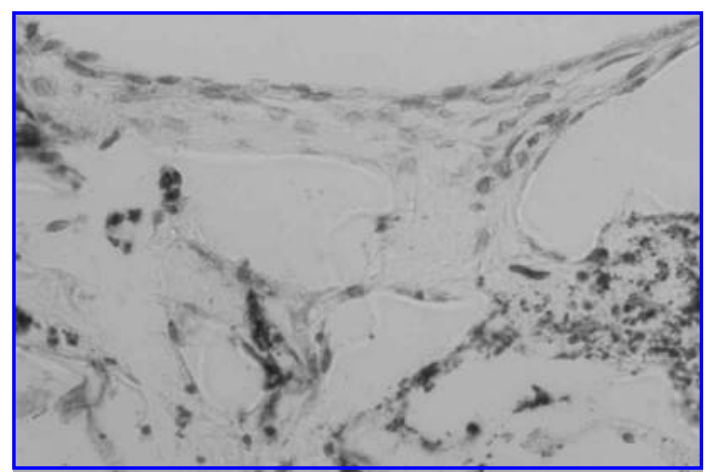

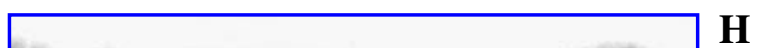

I

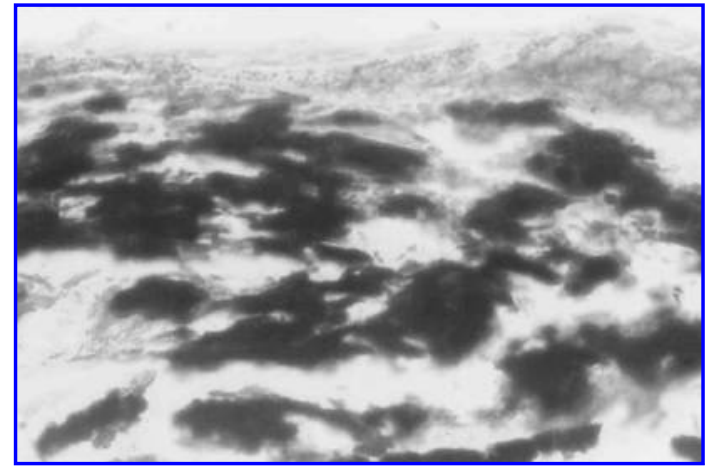

FIG. 2. (continued) 
bridization, blots were washed twice at $42^{\circ} \mathrm{C}$ and once at $65^{\circ} \mathrm{C}$ in two-fold SSC and $0.1 \%$ SDS and then twice at $65^{\circ} \mathrm{C}$ in 0.1 -fold SSC and $0.1 \%$ SDS (30 min per wash). Blots were detected and quantitatively scanned using an InstantImager (Model A2024, Packard Instrument Co, Downers Grove, IL). All values were normalized for RNA loading by probing blots with cDNA to $18 \mathrm{~S}$ rRNA. ${ }^{21}$

\section{Electron microscopy}

Matrices containing cells were fixed in $1 \%$ glutaraldehyde (Sigma) for $30 \mathrm{~min}$ and subsequently in $0.1 \%$ formaldehyde for 1 day. Samples were then dehydrated, mounted, sputter-coated with gold (Desk II, Denton Vacuum, Cherry Hill, NJ), and imaged with a scanning electron microscope (ISI-DS 130, Topcon).

\section{Mechanical testing}

Compression testing was performed on an MTS Bionix 100 (Sintech, Research Triangle Park, NC). A constant strain rate of $1 \mathrm{~mm} / \mathrm{min}$ was used, and moduli were determined from the stress-strain curves for strains ranging from 0 to $5 \%$.

\section{RESULTS}

Osteoblasts were first seeded onto porous PLG matrices to confirm that MC3T3 cells would adhere to these materials. Highly porous PLG matrices (95\% porosity; Fig. 1A) were fabricated by a gas foaming/particulate leaching process, ${ }^{9}$ and seeded with MC3T3 cells using a static seeding method. ${ }^{13}$ Cells adhered, spread, and formed a monolayer on the surfaces of the polymer (Fig. 1B). The initial cell density with this seeding method was $2.3 \times 10^{7}$ cells $/ \mathrm{mL}$ of scaffold, and the efficiency of cell adhesion to matrices was $46 \%$.

The osteogenic cells subsequently proliferated on the scaffold to form a three-dimensional tissue in a manner consistent with the proliferation stage of bone formation typically described for preosteoblasts in two-dimensional culture and in vivo. ${ }^{11}$ Examination of histological sections stained with hematoxylin and

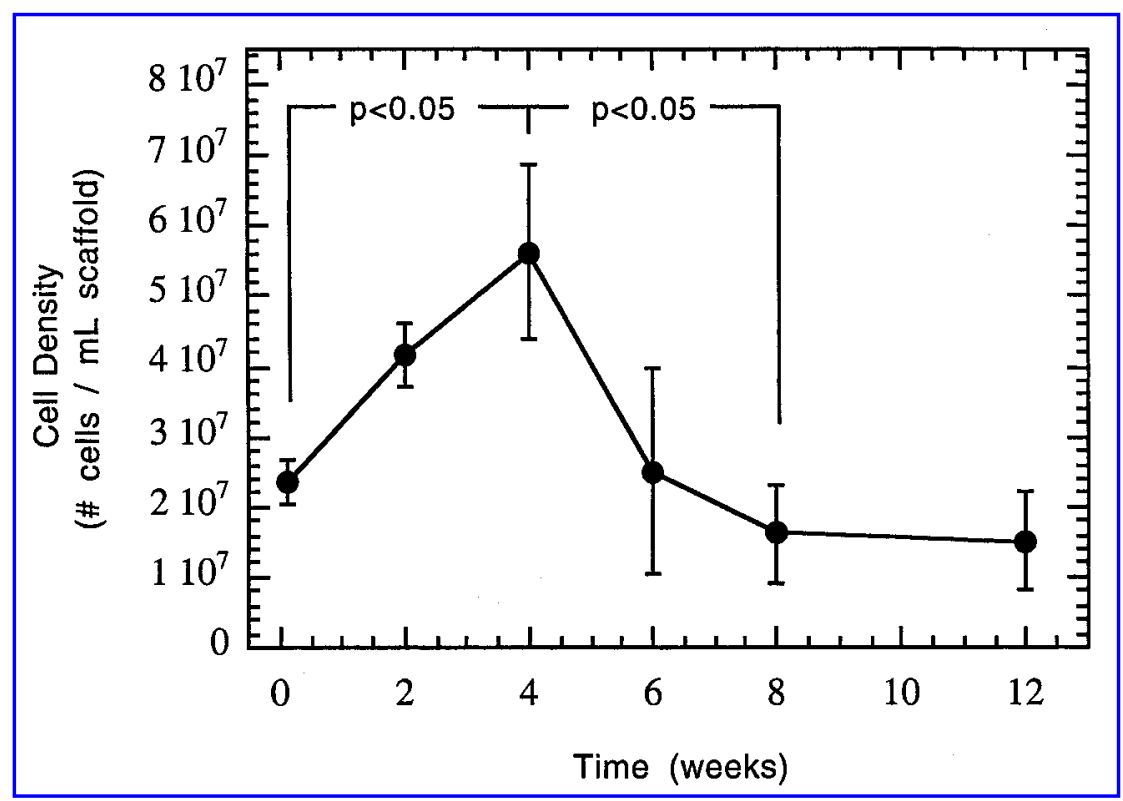

FIG. 3. MC3T3-E1 cell density during culture on PLG scaffolds. Cell density was calculated based on the quantity of DNA extracted from scaffolds at the times indicated. Increase in cell density from 1 to 4 weeks and the decrease in cell density from 4 to 8 weeks is statistically significant $(p<0.05)$. The cell density is reported as the number of cells per milliliter of scaffold. Values represent mean and standard deviation $(n=3)$. 


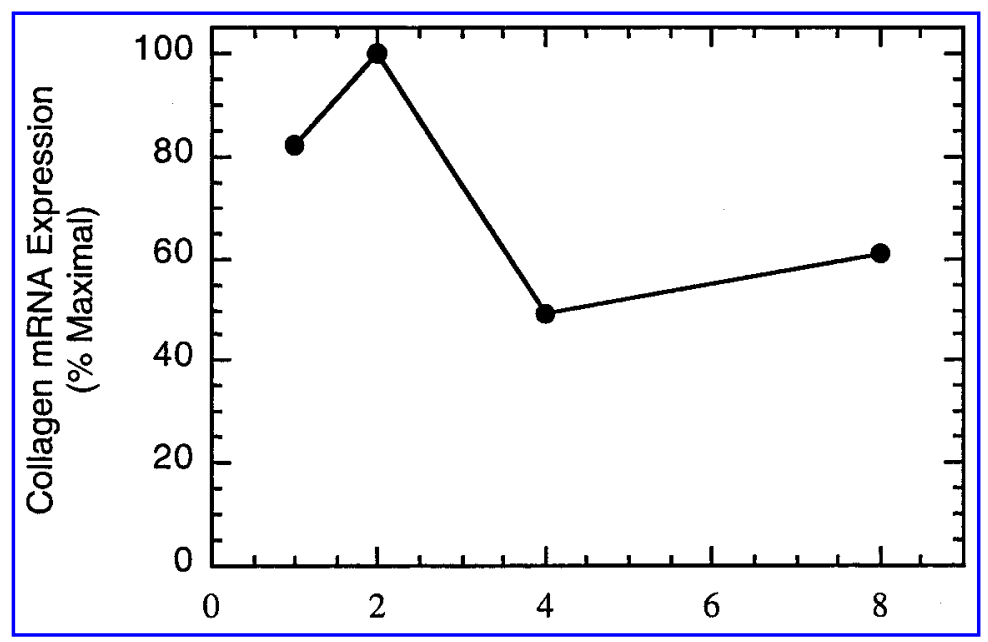

FIG. 4. Extracellular matrix gene expression. Total RNA was extracted from cells cultured on PLG scaffolds for the indicated times. Northern blots for collagen type I (COL) and ribosomal RNA (rRNA) were performed for samples obtained at $1,2,4$, and 8 weeks of culture. The 8 -week sample was run on a separate gel; however, hybridization was performed at the same time for all samples. Collagen type I expression levels were quantified and normalized to rRNA.

eosin (Fig. 2A,D,G) qualitatively confirmed cell proliferation during the early stage of tissue development. A loosely organized confluent cell layer, approximately 2-3 cells thick, was observed near the surface of the polymer (Fig. 2A). The cell density remained high in the $100 \mu \mathrm{m}$ below this confluent surface cell layer, but deeper into the tissue the cell density was decreased. After 4 weeks of culture, the surface confluent cell layer had increased to a thickness of approximately 4-5 cells (Fig. 2D), and the cell density remained high within the $150 \mu \mathrm{m}$ immediately below the surface. The cellular organization of the engineered tissue had similarities to that of native bone. Cells at the surface had organized into a single layer (Fig. 2G) with osteocyte-like cells entrapped within the collagen extracellular matrix to a depth of $200 \mu \mathrm{m}$. The cell density within the engineered tissue was quantified and found to increase during the first 4 weeks of culture

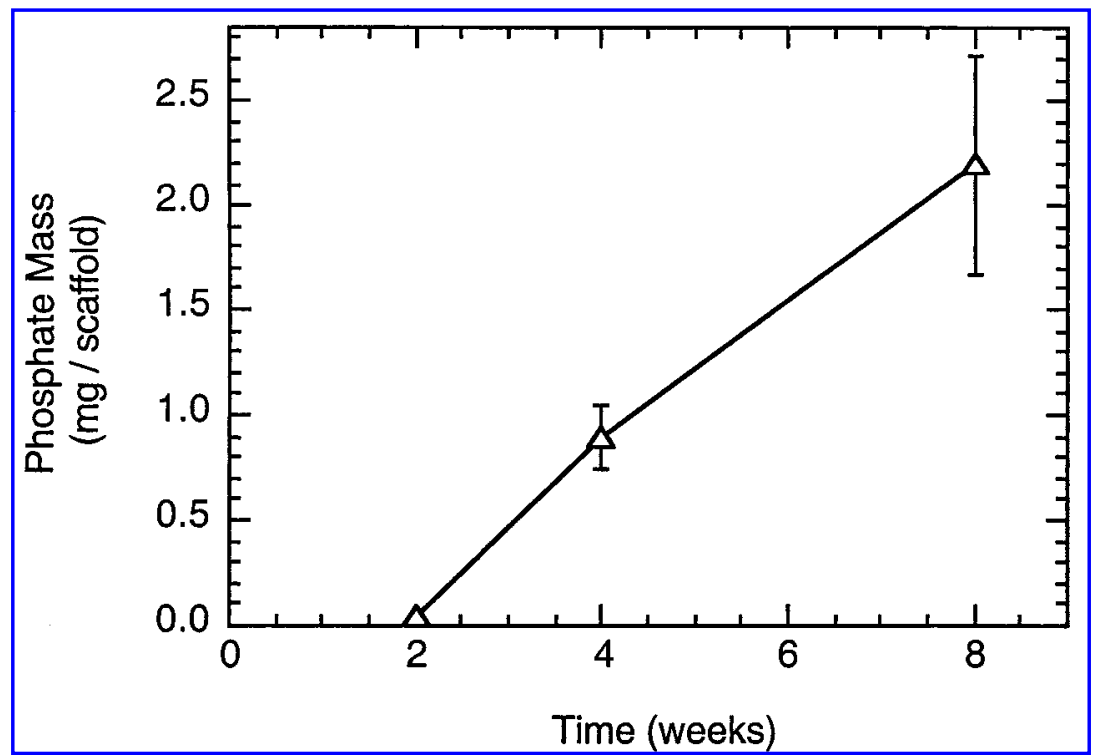

FIG. 5. Mineral deposition on PLG scaffolds by MC3T3-E1 cells. Phosphates were extracted at indicated times from tissues engineered with PLG scaffolds and MC3T3-E1 cells. Values represent mean and standard deviation $(n=3)$ with the means being statistically different $(p<0.05)$. 
(Fig. 3A), consistent with the proliferative phase of osteoblast differentiation. A subsequent decrease in cell density was observed, most likely due to cell necrosis in the scaffold interior resulting from limited nutrient availability.

Cells cultured on the polymer scaffold continuously deposit extracellular matrix (e.g., collagen), a prerequisite for the mineralization phase, throughout the time in culture. Histological sections stained with Masson's trichrome qualitatively demonstrate the increase in the quantity of collagen deposited with time (Fig. 2B,E,H). Collagen is initially deposited within $100 \mu \mathrm{m}$ of the surface, with more collagen being deposited in the region between 30 and $100 \mu \mathrm{m}$ below the surface (Fig. 2B). Collagen deposition increases through 4 weeks in culture and appears uniformly distributed in the region between 30 and $150 \mu \mathrm{m}$ of the

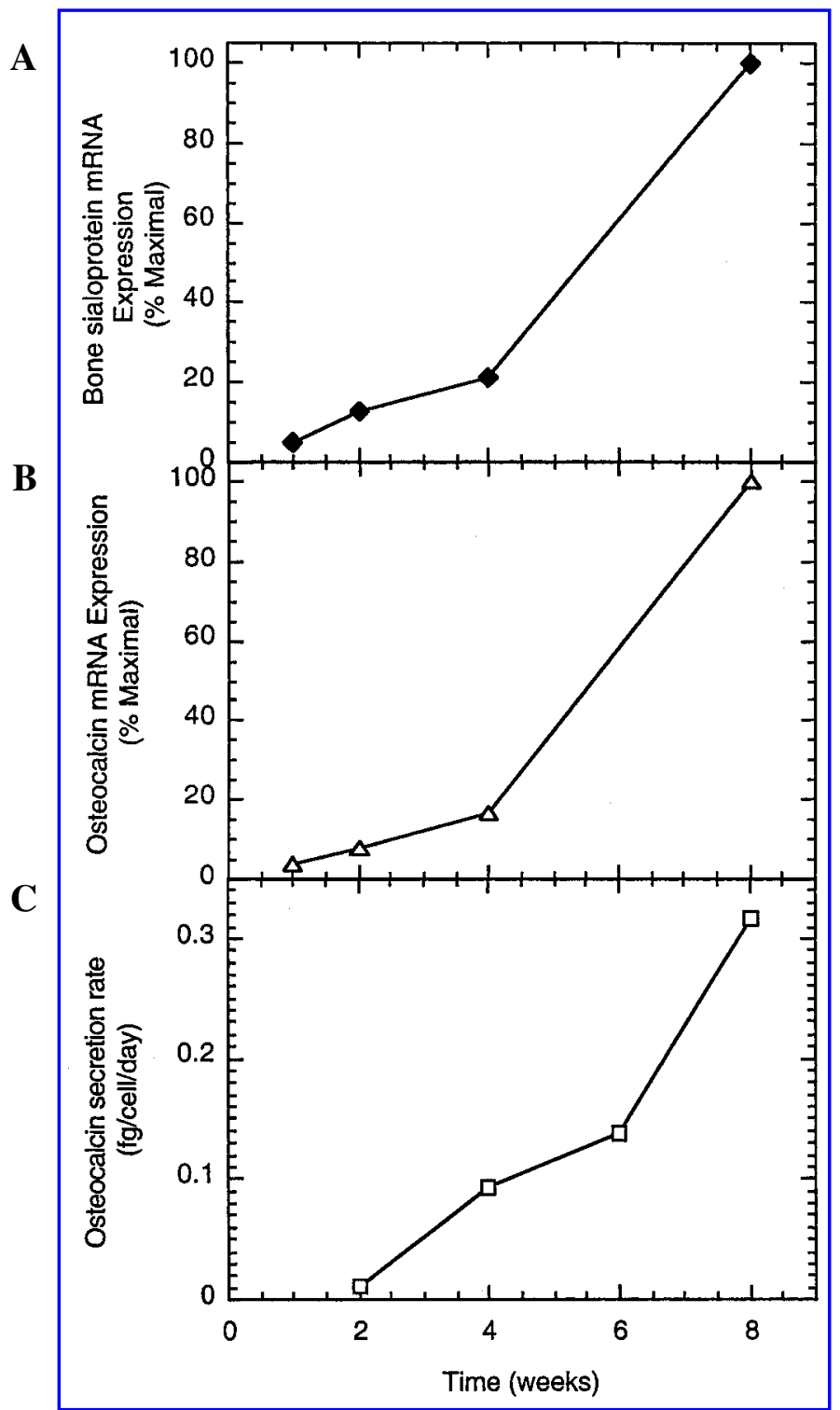

FIG. 6. Osteoblast marker gene expression. Total RNA was extracted from cells cultured on PLG scaffolds for the indicated times. Northern blot was used to examine expression of two osteoblast-specific markers (bone sialoprotein, BSP, and osteocalcin, OCN) at 1,2, 4, and 8 weeks of culture. The 8-week sample was run on a separate gel; however, hybridization was performed at the same time for all samples. Expression levels were quantified at each time point and normalized to ribosomal RNA for BSP $(\diamond)(\mathbf{A})$ and $\mathrm{OCN}(\triangle)(\mathbf{B})$. In addition, the production rates for osteocalcin $(\square)$ (C) were determined by assaying the media surrounding the tissues developing on PLG scaffolds. 
surface (Fig. 2E). Ultimately, the deposited collagen is observed at high density, and was continuously distributed from the surface to a depth of $200 \mu \mathrm{m}$ (Fig. 2H). Messenger RNA levels for type I collagen (Fig. 4A) were quantified and normalized to ribosomal RNA levels for all times in culture. Maximal collagen mRNA levels were observed at the 2-week time point; however, the mRNA levels never decreased below $50 \%$ of the maximum level. The presence of collagen mRNA at all times is consistent with the observed increase in collagen deposition throughout the time in culture.

Mineralization of the deposited extracellular matrix, the final phase of osteoblast differentiation, was observed after 4 weeks in culture. During this time, cells also expressed genes that signify formation of the osteoblast phenotype. Visualization of von Kossa-stained histologic sections from 4-week cultures revealed nodules of mineral occurring sporadically within $150 \mu \mathrm{m}$ of the scaffold surface (Fig. 2F). Ultimately, mineral was distributed uniformly from the scaffold surface to a depth of $200 \mu \mathrm{m}$ (Fig. 2I). Mineral deposition was not observed in control samples cultured in the absence of ascorbic acid and $\beta$-glycerol phosphate (data not shown). Total scaffold-associated phosphate, one component of the mineral in bone, was quantified as a measure of mineral deposition in the engineered tissues. Phosphate was not detected at the earliest time point. However, the mass of phosphates increased during the remainder of the experiment, consistent with histological observations (Fig. 5). Formation of the osteoblast phenotype was confirmed by verifying the expression of two osteoblast specific genes, bone sialoprotein (BSP) and osteocalcin (OCN), proteins with postulated roles in matrix mineralization. Messenger RNA levels for BSP (Fig. 6A) and OCN (Fig. 6B) during the first 4 weeks in culture were low $(<20 \%$ of maximum). A significant increase in expression of BSP and OCN was observed at 8 weeks in culture, which corresponds with the increase in mineralization observed in histological sections. Additionally, the OCN secretion rate was found to increase with time in culture consistent with the observed increase in its mRNA level (Fig. 6C).

Culture of osteogenic cells on porous PLG matrices led to the formation of a mechanically stable threedimensional engineered tissue. The compressional modulus of the engineered tissue was determined as one measure of the mechanical properties of the tissue. Prior to matrix mineralization, the developing tissue exhibited mechanical properties similar to that of the original polymer scaffold (Fig. 7). However, a doubling of the compressive modulus was observed for the engineered tissue at the last time point, which corresponds with the timing for matrix mineralization. A significant increase in the mechanical properties was not seen for control scaffolds not seeded with cells (data not shown). Importantly, the scaffold had sufficient me-

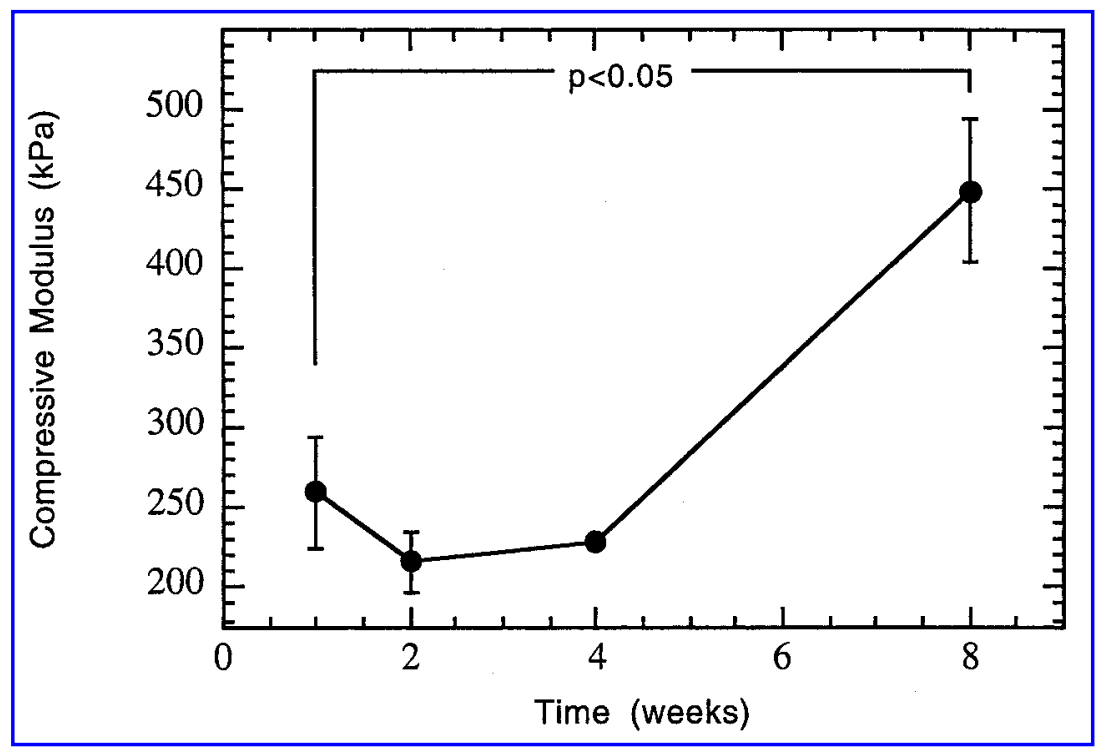

FIG. 7. Mechanical properties of engineered tissue. The compressive moduli of the developing tissue and an unseeded scaffold was measured at the indicated times. Increase in mechanical properties at the 8 weeks time point is statistically significant $(p<0.01)$. Values represent mean and standard deviation $(n=3)$. 


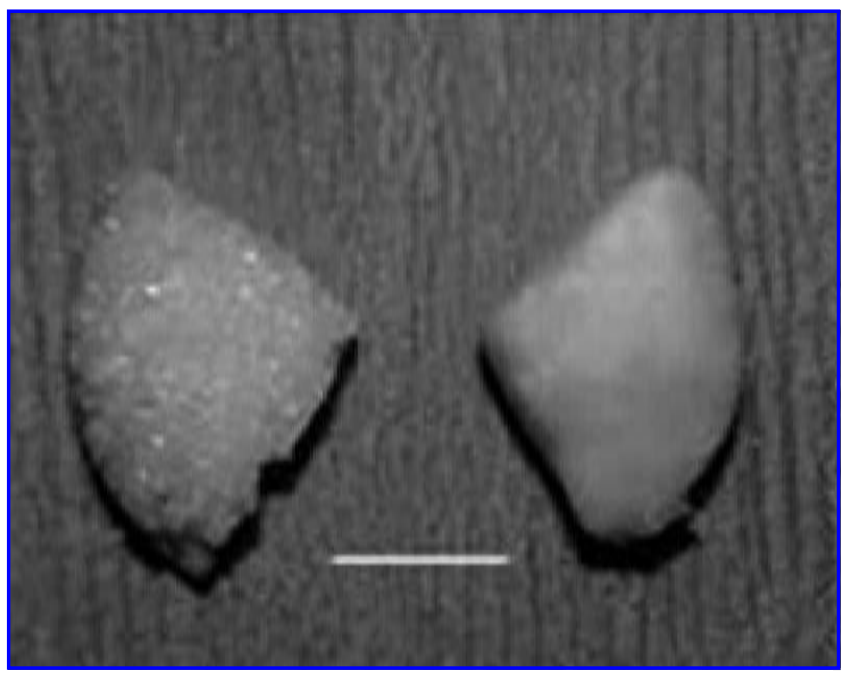

FIG. 8. Engineered tissue on PLG scaffold. Photograph of PLG scaffold not seeded with cells (left) and a PLG scaffold seeded with MC3T3-E1 cells (right) that was cultured for 12 weeks in a stirred bioreactor. White bars equals 5 $\mathrm{mm}$ in length.

chanical properties to guide tissue formation while maintaining the original shape and size of the polymer scaffold (Fig. 8).

\section{DISCUSSION}

The objective of this study was to determine if porous PLG matrices fabricated with a gas-foaming technique provide the appropriate environment for mineralized tissue formation from osteogenic cells. MC3T3E1 cells seeded onto the polymer scaffold attached and proliferated to form a three-dimensional tissue. The cells deposited an extracellular matrix of collagen and subsequently mineralized this deposited collagen. Matrix mineralization coincided with increased expression of bone sialoprotein and osteocalcin, thus confirming development of the osteoblast phenotype. Ultimately, cells form a mechanically stable three-dimensional mineralized tissue that maintains the size and shape of the original polymer scaffold.

MC3T3-E1 cells, a murine calvaria derived clonal cell line at the osteoprogenitor stage, ${ }^{22}$ were used to examine development of a mineralized tissue on these three-dimensional scaffolds. Both primary osteoblasts ${ }^{23}$ or stromal osteoblastic cells ${ }^{24,25}$ have been used previously to examine the ability of similar scaffolds to form mineralized tissues in vitro and in vivo. The use of a pre-osteoblast cell line in these studies provides a mechanism to obtain a homogeneous population of osteoprogenitor cells in large quantities. Although these transformed cells are inappropriate for in vivo therapeutic applications, MC3T3-E1 cells enable studies on the differentiation of osteoprogenitor cells, leading to the formation of a mineralized tissue. These cells retain several properties of primary osteoblast cultures including the ability to form a mineralized collagenous extracellular matrix and express osteoblast-related gene products in a defined temporal sequence. ${ }^{12,26,27}$

The scaffolds used in this study provide an environment that supports mineralized tissue formation and may ultimately be used to repair bone defects either by cell transplantation or by guiding bone regeneration. Previous experiments with porous scaffolds of PGA and PLG fabricated with solvent casting or extrusion processes have demonstrated the ability of these matrices to support the formation of a mineralized tissue. $^{23,28}$ A variety of scaffolding materials, such as collagen, hyaluronic acid, and hydroxyapatite, have been examined for their ability to support bone formation in vivo. ${ }^{29-32}$ One desirable attribute of the PLG polymer scaffold is that the degradation rate can be controlled through the ratio of lactide to glycolide in 
the polymer. Additionally, scaffolds formed by the gas foaming process may be advantageous because of the ability to deliver bioactive factors (e.g., growth factors, plasmid DNA) ${ }^{33,34}$ for extended times. The gas foaming process avoids the use of organic solvents or high temperatures, which can diminish the activity of many bioactive factors. Delivery of tissue-inductive factors (e.g., BMPs) from these matrices may facilitate tissue regeneration by stimulating the progenitor cells to enhance one or more of the steps (e.g., cell migration, proliferation, or differentiation) in the tissue regeneration process. Scaffolds seeded with cells could be implanted immediately or be cultured in vitro for a period of time before implantation. Alternatively, a scaffold alone could be implanted that would create and maintain a space in vivo while allowing the progenitor cells to migrate into the scaffold through the pores and ultimately regenerate the tissue. Importantly, for this guided tissue regeneration approach, the scaffold must have sufficient mechanical properties to retain its original dimensions following bone formation, which will be important for regenerating specific size defects.

Culture of osteo-progenitor cells on the polymer scaffolds also serves as an in vitro model system to examine the developmental pattern of osteoblasts within this engineered tissue. The accepted model of osteoblast differentiation ${ }^{11}$ describes a three-step process (proliferation, matrix maturation, and matrix mineralization) in which specific patterns of gene expression correlate with different steps. For the engineered tissue, the proliferative phase occurs during the first 4 weeks in culture and is characterized by an increase in cell density on the polymer scaffold. These cells deposit extracellular matrix protein (e.g., collagen) onto the polymer scaffold throughout the time in culture. Messenger RNA levels for type I collagen remain high ( $>50 \%$ of maximal expression) for all times, which is consistent with prior observations of MC3T3-E1 cells in two-dimensional culture. ${ }^{12}$ Mineralization begins to occur within the scaffold around 4 weeks in culture as observed by the sporadic distribution of mineral in the histological sections at this time. A significant increase in mineral deposition was observed during the remainder of the experiment, which corresponds to a significant increase in the mRNA levels for bone sialoprotein and osteocalcin. Bone sialoprotein and osteocalcin are proteins with a postulated role in matrix mineralization, and their up-regulated expression with mineralization is consistent with the accepted model of osteoblast differentiation. The development of the engineered tissue at both the tissue level (e.g., cell density, matrix content) and the cellular level (e.g., gene expression) is consistent with the model of development established for two dimensional culture systems.

The architecture of the engineered mineralized tissue exhibits a cellular organization similar to that of bone in vivo. Following the initial proliferative phase of osteoblast differentiation, the tissue develops such that a single layer of cells is observed on the surface of the scaffold. Below this surface layer, osteocytelike cells are entrapped within a mineralized extracellular matrix. However, the mechanical properties of the engineered tissue are significantly less than that of native bone, which could limit the immediate applications engineered tissue for bone replacement. For example, the compressive modulus of our engineered tissue is approximately $450 \mathrm{kPA}$ whereas the compressive moduli of compact bone and trabecular bone is approximately $10 \mathrm{GPa}$ and $50 \mathrm{Mpa} .{ }^{1}$ Mechanical stimulation of the developing tissue may enhance the mechanical properties of the tissue ${ }^{35}$; however, the significantly decreased mechanical properties of these tissues are due primarily to the relatively thin layer of tissue that forms $(\approx 200 \mu \mathrm{m})$. The onset of mineralization does coincide with an increase in mechanical properties; however, the inability to mineralize the entire scaffold limits the mechanical properties of the polymer/tissue composite. The thin shell of bone formed on the scaffold in this situation is most likely due to mass transport limitations inherent to this in vitro culture system. Cells within the engineered tissue in this system receive nutrients only by diffusion from the surrounding media into the tissue. A high cell density on the exterior of the scaffold may deplete the nutrient supply before the nutrients can diffuse to the scaffold interior. Cells on the interior of the polymer scaffold ultimately become necrotic because of inaccessibility to the nutrients. This limitation can ultimately be overcome in vivo by developing strategies to induce blood vessel ingrowth into the polymer scaffold from the surrounding tissue, allowing for large tissue masses to be engineered. ${ }^{33,36}$

This study, to our knowledge, is the first to demonstrate that the development of a three-dimensional engineered bone tissue from progenitor cells follows the pattern of differentiation typically observed in vivo and in two-dimensional culture systems. The PLG scaffold fabricated by the gas foaming process serves as 
a suitable substrate for the formation of a three-dimensional mineralized tissue and these scaffolds, possibly in combination with a sustained delivery of tissue-inductive factors, may find utility in enhancing bone regeneration in vivo.

\section{ACKNOWLEDGMENTS}

Funding for this research was provided by National Institutes of Health (NIH) Grant DE13033, NIDR postdoctoral fellowship DE07057, and Reprogenesis.

\section{REFERENCES}

1. Yaszemski, M.J., Payne, R.G., Hayes, W.C., Langer, R., and Mikos, A.G. Evolution of bone transplantation:molecular, cellular and tissue strategies to engineer human bone. Biomaterials 17, 175, 1996.

2. Brown, L.J., Brunelle, J.A., and Kingman, A. Periodontal status in the United States, 1988-1991: prevalence, extent, and demographic variation. J. Dent. Res. 75 Spec. No., 672, 1996.

3. Aaboe, M., Pinholt, E.M., and Hjorting-Hansen, E. Healing of experimental created defects: a review. Br. J. Oral Maxillofac. Surg. 33, 312, 1995.

4. Hermann, J.S., and Buser, D. Guided bone regeneration for dental implants. Curr. Opin. Periodontol. 3, 168, 1996.

5. Douthitt, J.C. Guided tissue regeneration in surgical endodontics: improving the prognosis of periradicular surgery. Tex. Dent. J. 114, 8, 1997.

6. Langer, R., and Vacanti, J.P. Tissue engineering. Science 260, 920, 1993.

7. Putnam, A.J., and Mooney, D.J. Tissue engineering using synthetic extracellular matrices. Nature Med. 2, 824, 1996.

8. Wake, M.C., Patrick, C.W., Jr., and Mikos, A.G. Pore morphology effects on the fibrovascular tissue growth in porous polymer substrates. Cell Transplant. 3, 339, 1994.

9. Harris, L.D., Kim, B.S., and Mooney, D.J. Open pore biodegradable matrices formed with gas foaming. J. Biomed. Mater. Res. 42, 396, 1998.

10. Wong, W.H., and Mooney, D.J. Synthesis and properties of biodegradable polymers used as synthetic matrices for tissue engineering. In Synthetic Biodegradable Polymer Scaffolds. Atala, A. and Mooney, D.J., eds. Birkhauser: Boston 1997, pp. 49-80.

11. Stein, G.S., Lian, J.B., and Owen, T.A. Relationship of cell growth to the regulation of tissue-specific gene expression during osteoblast differentiation. FASEB J. 4, 3111, 1990.

12. Franceschi, R.T., Iyer, B.S., and Cui, Y. Effects of ascorbic acid on collagen matrix formation and osteoblast differentiation in murine MC3T3-E1 cells. J. Bone Min. Res. 9, 843, 1994.

13. Kim, B.S., Putnam, A.J., Kulik, T.J., and Mooney, D.J. Optimizing seeding and culture methods to engineer smooth muscle tissue on biodegradable polymer matrices. Biotechnol. Bioeng. 57, 46, 1998.

14. Carson, F.L. Histotechnology: A Self Instructional Text. ASCP Press, 1990.

15. Heinonen, J.K., and Lahti, R.J. A new and convenient colorimetric determination of inorganic orthophosphate and its application to the assay of inorganic pyrophosphatase. Anal. Biochem. 113, 313, 1981.

16. Chomczynski, P., and Sacchi, N. Single-step method of RNA isolation by acid guanidinium thiocyanate- phenolchloroform extraction. Anal. Biochem. 162, 156, 1987.

17. Thomas, P.S. Hybridization of denatured RNA and small DNA fragments transferred to nitrocellulose. Proc. Natl. Acad. Sci. USA 77, 5201, 1980.

18. Celeste, A.J., Rosen, V., Buecker, J.L., Kriz, R., Wang, E.A., and Wozney, J.M. Isolation of the human gene for bone gla protein utilizing mouse and rat cDNA clones. EMBO J. 5, 1885, 1986.

19. Young, M.F., Ibaraki, K., Kerr, J.M., Lyu, M.S., and Kozak, C.A. Murine bone sialoprotein (BSP): cDNA cloning, mRNA expression, and genetic mapping. Mamm. Genome 5, 108, 1994.

20. Chu, M.L., Myers, J.C., Bernard, M.P., Ding, J.F., and Ramirez, F. Cloning and characterization of five overlapping cDNAs specific for the human pro alpha 1(I) collagen chain. Nucleic Acids Res. 10, 5925, 1982.

21. Renkawitz, R., Gerbi, S.A., and Glatzer, K.H. Ribosomal DNA of fly Sciara coprophila has a very small and homogeneous repeat unit. Mol. Gen. Genet. 173, 1979.

22. Sudo, H., Kodama, H.A., Amagai, Y., Yamamoto, S., and Kasai, S. In vitro differentiation and calcification in a new clonal osteogenic cell line derived from newborn mouse calvaria. J. Cell. Biol. 96, 191, 1983. 


\section{BONE DEVELOPMENT ON POLYMER SCAFFOLD}

23. Ishaug-Riley, S.L., Crane-Kruger, G.M., Yaszemski, M.J., and Mikos, A.G. Three-dimensional culture of rat calvarial osteoblasts in porous biodegradable polymers. Biomaterials 19, 1405, 1998.

24. Ishaug, S.L., Crane, G.M., Miller, M.J., Yasko, A.W., Yaszemski, M.J., and Mikos, A.G. Bone formation by threedimensional stromal osteoblast culture in biodegradable polymer scaffolds. J. Biomed. Mater. Res. 36, 17, 1997.

25. Ishaug-Riley, S.L., Crane, G.M., Gurlek, A., Miller, M.J., Yasko, A.W., Yaszemski, M.J., and Mikos, A.G. Ectopic bone formation by marrow stromal osteoblast transplantation using poly(DL-lactic-co-glycolic acid) foams implanted into the rat mesentery. J. Biomed. Mater. Res. 36, 1, 1997.

26. Franceschi, R.T., and Iyer, B.S. Relationship between collagen synthesis and expression of the osteoblast phenotype in MC3T3-E1 cells. J. Bone Min. Res. 7, 235, 1992.

27. Quarles, L.D., Yohay, D.A., Lever, L.W., Caton, R., and Wenstrup, R.J. Distinct proliferative and differentiated stages of murine MC3T3-E1 cells in culture: an in vitro model of osteoblast development. J. Bone Min. Res. 7, 683, 1992.

28. Vacanti, C.A., Kim, W., Upton, J., Vacanti, M.P., Mooney, D., Schloo, B., and Vacanti, J.P. Tissue-engineered growth of bone and cartilage. Transplant. Proc. 25, 1019, 1993.

29. Dennis, J.E., and Caplan, A.I. Porous ceramic vehicles for rat-marrow-derived (Rattus norvegicus) osteogenic cell delivery: effects of pre-treatment with fibronectin or laminin. J. Oral Implantol. 19, 106, 1993.

30. Krebsbach, P.H., Kuznetsov, S.A., Satomura, K., Emmons, R.V., Rowe, D.W., and Robey, P.G. Bone formation in vivo: comparison of osteogenesis by transplanted mouse and human marrow stromal fibroblasts. Transplantation 63, 1059, 1997.

31. Kuznetsov, S.A., Krebsbach, P.H., Satomura, K., Kerr, J., Riminucci, M., Benayahu, D., and Robey, P.G. Singlecolony derived strains of human marrow stromal fibroblasts form bone after transplantation in vivo. J. Bone Min. Res. 12, 1335, 1997.

32. Solchaga, L.A., Dennis, J.E., Goldberg, V.M., and Caplan, A.I. Hyaluronic acid-based polymers as cell carriers for tissue-engineered repair of bone and cartilage. J. Orthop. Res. 17, 205, 1999.

33. Sheridan, M.H., Shea, L.D., Peters, M.C., and Mooney, D.J. Bioabsorbable polymer scaffolds for tissue engineering capable of sustained growth factor delivery. J. Cont. Rel. 64, 91-102, 2000.

34. Shea, L.D., Smiley, E., Bonadio, J., and Mooney, D.J. Controllable DNA delivery from three-dimensional polymer matrices for tissue engineering. Nat. Biotech. 17, 551, 1999.

35. Niklason, L.E., Gao, J., Abbott, W.M., Hirschi, K.K., Houser, S., Marini, R., and Langer, R. Functional arteries grown in vitro. Science 284, 489, 1999.

36. Eiselt, P., Kim, B.S., Chacko, B., Isenberg, B., Peters, M.C., Greene, K.G., Roland, W.D., Loebsack, A.B., Burg, K.J., Culberson, C., Halberstadt, C.R., Holder, W.D., and Mooney, D.J. Development of technologies aiding largetissue engineering. Biotechnol. Prog. 14, 134, 1998.

Address reprint requests to: David Mooney, Ph.D.

Dept. Biologic and Materials Science University of Michigan

Dental School

1011 N. University

Ann Arbor, MI 48109-1078

E-mail: mooneyd@umich.edu 


\section{This article has been cited by:}

1. Amir A. Al-Munajjed, Niamh A. Plunkett, John P. Gleeson, Tim Weber, Christian Jungreuthmayer, Tanya Levingstone, Joachim Hammer, Fergal J. O'Brien. 2009. Development of a biomimetic collagen-hydroxyapatite scaffold for bone tissue engineering using a SBF immersion technique. Journal of Biomedical Materials Research Part B: Applied Biomaterials 90B:2, 584-591. [CrossRef]

2. Nareg A. Gharibjanian, Walter C. Chua, Sanjay Dhar, Thomas Scholz, Terry Y. Shibuya, Gregory R. D. Evans, Jay W. Calvert. 2009. Release Kinetics of Polymer-Bound Bone Morphogenetic Protein-2 and Its Effects on the Osteogenic Expression of MC3T3-E1 Osteoprecursor Cells. Plastic and Reconstructive Surgery 123:4, 1169-1177. [CrossRef]

3. S. S. Liji Sobhana, J. Sundaraseelan, S. Sekar, T. P. Sastry, A. B. Mandal. 2009. Gelatin-Chitosan composite capped gold nanoparticles: a matrix for the growth of hydroxyapatite. Journal of Nanoparticle Research 11:2, 333-340. [CrossRef]

4. Simon Young, Zarana S. Patel, James D. Kretlow , Matthew B. Murphy, Paschalia M. Mountziaris , L. Scott Baggett, Hiroki Ueda, Yasuhiko Tabata, John A. Jansen, Mark Wong, Antonios G. Mikos . Dose Effect of Dual Delivery of Vascular Endothelial Growth Factor and Bone Morphogenetic Protein-2 on Bone Regeneration in a Rat Critical-Size Defect ModelDose Effect of Dual Delivery of Vascular Endothelial Growth Factor and Bone Morphogenetic Protein-2 on Bone Regeneration in a Rat Critical-Size Defect Model. Tissue Engineering Part A, ahead of print. [Abstract] [PDF] [PDF Plus]

5. Shih-Hsin Chang, Yuan-Ming Hsu, Yng Jiin Wang, Yeou-Ping Tsao, Kwan-Yi Tung, Tao-Yuan Wang. 2009. Fabrication of pre-determined shape of bone segment with collagen-hydroxyapatite scaffold and autogenous platelet-rich plasma. Journal of Materials Science: Materials in Medicine 20:1, 23-31. [CrossRef]

6. Meghan J. Cuddihy , Nicholas A. Kotov . 2008. Poly(lactic-co-glycolic acid) Bone Scaffolds with Inverted Colloidal Crystal GeometryPoly(lactic-co-glycolic acid) Bone Scaffolds with Inverted Colloidal Crystal Geometry. Tissue Engineering Part A 14:10, 1639-1649. [Abstract] [PDF] [PDF Plus]

7. Yanyin Yang, Durgadas Bolikal, Matthew L. Becker, Joachim Kohn, Diana N. Zeiger, Carl G. Simon. 2008. Combinatorial Polymer Scaffold Libraries for Screening Cell-Biomaterial Interactions in 3D. Advanced Materials 20:11, 2037-2043. [CrossRef]

8. Ruby I. Chen, Nathan D. Gallant, Jack R. Smith, Matt J. Kipper, Carl G. Simon. 2008. Time-dependent effects of pre-aging polymer films in cell culture medium on cell adhesion and spreading. Journal of Materials Science: Materials in Medicine 19:4, 1759-1766. [CrossRef]

9. Jennifer E. Phillips, Robert E. Guldberg, Andrés J. García . 2007. Dermal Fibroblasts Genetically Modified to Express Runx2/Cbfa1 as a Mineralizing Cell Source for Bone Tissue EngineeringDermal Fibroblasts Genetically Modified to Express Runx2/Cbfa1 as a Mineralizing Cell Source for Bone Tissue Engineering. Tissue Engineering 13:8, 2029-2040. [Abstract] [PDF] [PDF Plus]

10. J. F. Mano, R. L. Reis. 2007. Osteochondral defects: present situation and tissue engineering approaches. Journal of Tissue Engineering and Regenerative Medicine 1:4, 261-273. [CrossRef]

11. Aylin Sendemir-Urkmez, Russell D. Jamison. 2007. The addition of biphasic calcium phosphate to porous chitosan scaffolds enhances bone tissue developmentin vitro. Journal of Biomedical Materials Research Part A 81A:3, 624-633. [CrossRef]

12. K. S. Stashevskaya, E. A. Markvicheva, S. M. Strukova, A. V. Rusanova, A. M. Makarova, L. R. Gorbacheva, I. A. Prudchenko, V. P. Zubov, K. Grandfis. 2007. Biodegradable microparticles 
with immobilized peptide for wound healing. Biochemistry (Moscow) Supplement Series B: Biomedical Chemistry 1:2, 147-154. [CrossRef]

13. Guofu Xu, Shenzhou Mou, Zhimin Yin, Lingping Zhou, Fuzhai Cui, Susan Liao. 2007. Biomimetic strengthening polylactide scaffold materials for bone tissue engineering. Frontiers of Chemistry in China 2:1, 27-30. [CrossRef]

14. J Venugopal, P Vadgama, T S Sampath Kumar, S Ramakrishna. 2007. Biocomposite nanofibres and osteoblasts for bone tissue engineering. Nanotechnology 18:5, 055101. [CrossRef]

15. Ming Chen, Prabir K. Patra, Steven B. Warner, Sankha Bhowmick . 2007. Role of Fiber Diameter in Adhesion and Proliferation of NIH 3T3 Fibroblast on Electrospun Polycaprolactone Scaffolds. Tissue Engineering 13:3, 579-587. [Abstract] [PDF] [PDF Plus]

16. Ming Chen, Prabir K. Patra, Steven B. Warner, Sankha Bhowmick. 2007. Role of Fiber Diameter in Adhesion and Proliferation of NIH 3T3 Fibroblast on Electrospun Polycaprolactone Scaffolds. Tissue Engineering, ahead of print070110055731001. [CrossRef]

17. Carl G. Simon, Jean S. Stephens, Shauna M. Dorsey, Matthew L. Becker. 2007. Fabrication of combinatorial polymer scaffold libraries. Review of Scientific Instruments 78:7, 072207. [CrossRef]

18. Angel O. Duty, Megan E. Oest, Robert E. Guldberg. 2007. Cyclic Mechanical Compression Increases Mineralization of Cell-Seeded Polymer Scaffolds In Vivo. Journal of Biomechanical Engineering 129:4, 531. [CrossRef]

19. Christian Clausen, Niels Ulrich Hermund, Ole Donatsky, Henrik Nielsen. 2006. Characterization of human bone cells derived from the maxillary alveolar ridge. Clinical Oral Implants Research 17:5, 533-540. [CrossRef]

20. Danielle S.W. Benoit, Andrew R. Durney, Kristi S. Anseth. 2006. Manipulations in Hydrogel Degradation Behavior Enhance Osteoblast Function and Mineralized Tissue Formation. Tissue Engineering, ahead of print060706073730047. [CrossRef]

21. Susan X. Hsiong, David J. Mooney. 2006. Regeneration of vascularized bone. Periodontology 2000 41:1, 109-122. [CrossRef]

22. Danielle S.W. Benoit , Andrew R. Durney , Kristi S. Anseth . 2006. Manipulations in Hydrogel Degradation Behavior Enhance Osteoblast Function and Mineralized Tissue FormationManipulations in Hydrogel Degradation Behavior Enhance Osteoblast Function and Mineralized Tissue Formation. Tissue Engineering 12:6, 1663-1673. [Abstract] [PDF] [PDF Plus]

23. Manuela E. Gomes, Heidi L. Holtorf, Rui L. Reis , Antonios G. Mikos . 2006. Influence of the Porosity of Starch-Based Fiber Mesh Scaffolds on the Proliferation and Osteogenic Differentiation of Bone Marrow Stromal Cells Cultured in a Flow Perfusion BioreactorInfluence of the Porosity of Starch-Based Fiber Mesh Scaffolds on the Proliferation and Osteogenic Differentiation of Bone Marrow Stromal Cells Cultured in a Flow Perfusion Bioreactor. Tissue Engineering 12:4, 801-809. [Abstract] [PDF] [PDF Plus]

24. Liat Abramovitch-Gottlib, Shimona Geresh , Razi Vago . 2006. Biofabricated Marine Hydrozoan: A Bioactive Crystalline Material Promoting Ossification of Mesenchymal Stem CellsBiofabricated Marine Hydrozoan: A Bioactive Crystalline Material Promoting Ossification of Mesenchymal Stem Cells. Tissue Engineering 12:4, 729-739. [Abstract] [PDF] [PDF Plus]

25. Jue-Yeon Lee, Kyoung-Hwa Kim, Seung-Yoon Shin, In-Chul Rhyu, Yong-Moo Lee, Yoon-Jeong Park, Chong-Pyoung Chung, Seung-Jin Lee. 2006. Enhanced bone formation by transforming growth factor- $\beta 1$-releasing collagen/chitosan microgranules. Journal of Biomedical Materials Research Part A 76A:3, 530-539. [CrossRef] 
26. Ruth Z. Birk, Liat Abramovitch-Gottlib, Iris Margalit, Moran Aviv, Efrat Forti, Shimona Geresh, Razi Vago. 2006. Conversion of Adipogenic to Osteogenic Phenotype Using Crystalline Porous Biomatrices of Marine Origin. Tissue Engineering, ahead of print060118075515007. [CrossRef]

27. Dr. Ruth Z. Birk, Liat Abramovitch-Gottlib , Iris Margalit, Moran Aviv, Efrat Forti , Prof. Shimona Geresh , Razi Vago . 2006. Conversion of Adipogenic to Osteogenic Phenotype Using Crystalline Porous Biomatrices of Marine OriginConversion of Adipogenic to Osteogenic Phenotype Using Crystalline Porous Biomatrices of Marine Origin. Tissue Engineering 12:1, 21-31. [Abstract] [PDF] [PDF Plus]

28. Sachin Shanbhag, Shaopeng Wang, Nicholas A. Kotov. 2006. Cell Distribution Profiles in Three-Dimensional Scaffolds with Inverted-Colloidal-Crystal Geometry: Modeling and Experimental Investigations. Small 1:12, 1208-1214. [CrossRef]

29. Liat Abramovitch-Gottlib, Talia Gross, Doron Naveh, Shimona Geresh, Salman Rosenwaks, Ilana Bar, Razi Vago. 2006. Low level laser irradiation stimulates osteogenic phenotype of mesenchymal stem cells seeded on a three-dimensional biomatrix. Lasers in Medical Science 20:3-4, 138-146. [CrossRef]

30. Jay W. Calvert, Walter C. Chua, Nareg A. Gharibjanian, Sanjay Dhar, Gregory R. D. Evans. 2005. Osteoblastic Phenotype Expression of MC3T3-E1 Cells Cultured on Polymer Surfaces. Plastic and Reconstructive Surgery 116:2, 567-576. [CrossRef]

31. A. Kumarasuriyar , R.A. Jackson , L. Grøndahl , M. Trau , V. Nurcombe , S.M. Cool . 2005. Poly $(\beta$-hydroxybutyrate-co- $\beta$-hydroxyvalerate) Supports in Vitro OsteogenesisPoly $(\beta$-hydroxybutyrate-co- $\beta$-hydroxyvalerate) Supports in Vitro Osteogenesis. Tissue Engineering 11:7-8, 1281-1295. [Abstract] [PDF] [PDF Plus]

32. Lars Stangenberg, Dirk J. Schaefer, Olaf Buettner, Jan Ohnolz, Dieter Möbest, Raymund E. Horch , G. Björn Stark , Ulrich Kneser . 2005. Differentiation of Osteoblasts in Three-Dimensional Culture in Processed Cancellous Bone Matrix: Quantitative Analysis of Gene Expression Based on Real-Time Reverse Transcription- Polymerase Chain ReactionDifferentiation of Osteoblasts in Three-Dimensional Culture in Processed Cancellous Bone Matrix: Quantitative Analysis of Gene Expression Based on Real-Time Reverse Transcription- Polymerase Chain Reaction. Tissue Engineering 11:5-6, 855-864. [Abstract] [PDF] [PDF Plus]

33. A. J. Salgado, J. E. Figueiredo, O. P. Coutinho, R. L. Reis. 2005. Biological response to pre-mineralized starch based scaffolds for bone tissue engineering. Journal of Materials Science: Materials in Medicine 16:3, 267-275. [CrossRef]

34. Hong-Ru Lin, Yu-Jen Yeh. 2004. Porous alginate/hydroxyapatite composite scaffolds for bone tissue engineering: Preparation, characterization, andin vitro studies. Journal of Biomedical Materials Research 71B:1, 52-65. [CrossRef]

35. S. S. Liao, F. Z. Cui, W. Zhang, Q. L. Feng. 2004. Hierarchically biomimetic bone scaffold materials: Nano-HA/collagen/PLA composite. Journal of Biomedical Materials Research 69B:2, 158-165. [CrossRef]

36. Edward A. Botchwey, Solomon R. Pollack, Elliot M. Levine, Eric D. Johnston, Cato T. Laurencin. 2004. Quantitative analysis of three-dimensional fluid flow in rotating bioreactors for tissue engineering. Journal of Biomedical Materials Research 69A:2, 205-215. [CrossRef]

37. Orasa Anusaksathien, Qiming Jin, Ming Zhao, Martha J. Somerman, William V. Giannobile. 2004. Effect of Sustained Gene Delivery of Platelet-Derived Growth Factor or Its Antagonist (PDGF-1308) on Tissue-Engineered Cementum. Journal of Periodontology 75:3, 429-440. [CrossRef]

38. A.J. Salgado , O.P. Coutinho , R.L. Reis . 2004. Novel Starch-Based Scaffolds for Bone Tissue Engineering: Cytotoxicity, Cell Culture, and Protein ExpressionNovel Starch-Based Scaffolds for 
Bone Tissue Engineering: Cytotoxicity, Cell Culture, and Protein Expression. Tissue Engineering 10:3-4, 465-474. [Abstract] [PDF] [PDF Plus]

39. Michael Shin , Hiroshi Yoshimoto , Joseph P. Vacanti . 2004. In Vivo Bone Tissue Engineering Using Mesenchymal Stem Cells on a Novel Electrospun Nanofibrous ScaffoldIn Vivo Bone Tissue Engineering Using Mesenchymal Stem Cells on a Novel Electrospun Nanofibrous Scaffold. Tissue Engineering 10:1-2, 33-41. [Abstract] [PDF] [PDF Plus]

40. Q.-M. Jin, M. Zhao, S.A. Webb, J.E. Berry, M.J. Somerman, W.V. Giannobile. 2003. Cementum engineering with three-dimensional polymer scaffolds. Journal of Biomedical Materials Research 67A:1, 54-60. [CrossRef]

41. Edward A. Botchwey, Melissa A. Dupree, Solomon R. Pollack, Elliot M. Levine, Cato T. Laurencin. 2003. Tissue engineered bone: Measurement of nutrient transport in three-dimensional matrices. Journal of Biomedical Materials Research 67A:1, 357-367. [CrossRef]

42. A.J. Garcia, R.E. Guildberg, B.A. Byers, C.A. Gersbach, J.E. Phillips. 2003. Addressing cell-sourcing limitations with gene therapy - Genetic engineering with runx2/cbfa1 for an alternative to biological grafts. IEEE Engineering in Medicine and Biology Magazine 22:5, 65-70. [CrossRef]

43. Evan L. Dvorin, Jill Wylie-Sears, Sunjay Kaushal, David P. Martin, Joyce Bischoff . 2003. Quantitative Evaluation of Endothelial Progenitors and Cardiac Valve Endothelial Cells: Proliferation and Differentiation on Poly-glycolic acid/Poly-4-hydroxybutyrate Scaffold in Response to Vascular Endothelial Growth Factor and Transforming Growth Factor $\beta 1$ Quantitative Evaluation of Endothelial Progenitors and Cardiac Valve Endothelial Cells: Proliferation and Differentiation on Poly-glycolic acid/Poly-4-hydroxybutyrate Scaffold in Response to Vascular Endothelial Growth Factor and Transforming Growth Factor $\beta 1$. Tissue Engineering 9:3, 487-493. [Abstract] [PDF] [PDF Plus]

44. Jeffrey M. Karp, Molly S. Shoichet, John E. Davies. 2003. Bone formation on two-dimensional poly(DL-lactide-co-glycolide) (PLGA) films and three-dimensional PLGA tissue engineering scaffoldsin vitro. Journal of Biomedical Materials Research 64A:2, 388-396. [CrossRef]

45. Giuseppe Intini, Sebastiano Andreana, Joseph E. Margarone III , Peter J. Bush, Rosemary Dziak . 2002. Engineering a Bioactive Matrix by Modifications of Calcium SulfateEngineering a Bioactive Matrix by Modifications of Calcium Sulfate. Tissue Engineering 8:6, 997-1008. [Abstract] [PDF] [PDF Plus]

46. John P. Fisher, Johan W. M. Vehof, David Dean, Jan Paul C. M. van der Waerden, Theresa A. Holland, Antonios G. Mikos, John A. Jansen. 2002. Soft and hard tissue response to photocrosslinked poly(propylene fumarate) scaffolds in a rabbit model. Journal of Biomedical Materials Research 59:3, 547-556. [CrossRef]

47. Hong-Ru Lin, Chun-Jung Kuo, C. Y. Yang, Shyh-Yu Shaw, Yu-Jun Wu. 2002. Preparation of macroporous biodegradable PLGA scaffolds for cell attachment with the use of mixed salts as porogen additives. Journal of Biomedical Materials Research 63:3, 271-279. [CrossRef]

48. Jason A. Burdick, Robert F. Padera, Janice V. Huang, Kristi S. Anseth. 2002. An investigation of the cytotoxicity and histocompatibility ofin situ forming lactic acid based orthopedic biomaterials. Journal of Biomedical Materials Research 63:5, 484-491. [CrossRef]

49. Jane Lian, Gary Stein, Janet Stein. 2002. Current Opinion in Endocrinology \& Diabetes 8:6, 268-276. [CrossRef] 